\title{
Lactation Performance, Milk Fatty Acid Composition, and Blood Lipid Profile of Lactating Buffaloes in Response to Dietary Soybean and Linseed Oils
}

\author{
E. Eldahshan ${ }^{\mathrm{a}}$, E. Saddick ${ }^{\mathrm{a}}$, \& S. Selim ${ }^{\mathrm{b}, *}$ \\ a Department of Animal Production, Faculty of Agriculture, University of Menoufia \\ ${ }^{b}$ Department of Nutrition and Clinical Nutrition, Faculty of Veterinary Medicine, University of Menoufia \\ Shibin El-kom, 32514, Egypt \\ *Corresponding author: shimaaselim@vet.menofia.edu.eg \\ (Received 30-03-2020; Revised 13-06-2020; Accepted 25-06-2020)
}

\begin{abstract}
There is an awareness in augmenting conjugated linoleic acid (CLA) and n-3 fatty acids (FA), while lowering saturated FA (SFA) in ruminant milk due to their advantageous health benefits for humans. Therefore, we aimed to investigate the effects of soybean and linseed oils on milk yield, milk composition, milk FA profile, and blood lipid metabolites. Eighteen multiparous Egyptian buffaloes fed corn silage and clover hay-based diet were allocated at random for body weight, days in milk, and milk yield into 3 groups of 6 buffaloes each using a randomized block design. Dietary treatments consisted of three concentrate supplements containing no additional plant oil (CON) or containing soybean oil (SO) or linseed oil at a level of $2.6 \%$ of dry matter intake (DMI) (400 g/head/d; $25.6 \mathrm{~g} / \mathrm{kg}$ DMI). Moderate dietary inclusion of SO or LO had no detrimental effects on DMI, milk production, or milk fat per cent. Milk protein, lactose, ash, and total solids concentrations were increased by LO supplementation. The LO diet decreased milk total SFA content (C10:0, C12:0, C14:0, C16:0), augment monounsaturated FA (MUFA), 18:3n-3 FA, CLA, and polyunsaturated FA, as well as lower atherogenicity index and n-6:n-3 compared to CON. On the other hand, the SO diet increased milk fat content of n-6 FA, CLA, MUFA, and n-6:n-3, and decreased the atherogenicity index compared to CON. LO supplementation had no effect on serum concentrations of triglyceride, total lipids, HDL, and LDL. However, the SO group tended to have greater serum total lipids and LDL concentrations and significantly elevated level of serum cholesterol. In conclusion, dietary inclusion of LO in the concentrate supplement of dairy buffaloes could enrich the nutritive value of milk with advantageous FA (n-3 FA, MUFA, and CLA) and lower the atherogenicity index and $n 6$ to $n 3$ ratio without triggering any adverse effects on buffalo performance.
\end{abstract}

Keywords: buffaloes; plant oil; milk composition; milk fatty acid profile; blood metabolites

\section{INTRODUCTION}

Buffaloes are commonly allocated all over Asia, the Middle East, Europe, China, and South America. Buffaloes are considered as the second milk producing animal world-wide. The average milk production of lactating buffaloes in 2009 was approximately 90 million tons representing about $13 \%$ of the total world milk production with an annual rise of $3.1 \%$ in comparison to $1.3 \%$ annual rise in dairy cow milk production (IDF, 2010). Buffalo milk plays a vital role in the human diet predominantly in the developing countries and is favored by the Egyptian consumers because of its white color, high-fat content, and good flavor (El-Salam \& El-Shibiny, 2011). Compared with cow milk, buffalo milk is rich in nearly all the chief milk nutrients such as fat, protein, lactose, casein, and ash contents (El-Salam \& El-Shibiny, 2011). Buffalo's milk fat contained higher total saturated fatty acids (SFA, C12:0, C14:0, and C16:0) and lower monounsaturated fatty acids (MUFA) con- centrations than the cow's milk fat (Ménard et al., 2010; Gagliostro et al., 2015).

Milk and dairy products are vital constituents of healthy human diets because of their ability to supply their diets with essential macro- and micronutrients (Lordan et al., 2018). The consumption of dairy products is accompanied by several adverse health problems due to their SFA content, which may lead to the elevated blood low-density lipoprotein (LDL), and consequently may increase the risk of cardiovascular disease and lower insulin sensitivity in humans (Lordan et al., 2018). However, C18:0 fatty acid (FA) is considered as a neutral FA compared to MUFA because it increases circulating LDL-cholesterol concentrations (Shingfield et al., 2008). Besides, several branched-chain SFA and other bioactive lipids in the milk fat are thought to exhibit anticarcinogenic properties and positive effects concerning the decrease prevalence of chronic diseases in humans (Shingfield et al., 2008; Halmemies-Beauchet-Filleau et al., 2011). 
Due to the potential health benefits for humans, there is an awareness in augmenting cis-9, trans-11 conjugated linoleic acid (CLA) and polyunsaturated n-3 FA, while decreasing medium-chain FA in the milk of dairy cows through plant oils supplementation (Shingfield et al., 2013; Kairenius et al., 2018; Mahdavi et al., 2019). To our knowledge, the effect of plant oils varying in linoleic or linolenic acid concentrations (soybean oil and linseed oil) on milk composition, milk fatty acids profile, and blood lipid constituents in lactating buffaloes are very limited. Therefore, the objectives of the present study were to enrich the milk of lactating buffaloes with beneficial FA (C18:3 n-3, CLA) and decrease milk n6:n3 ratio through supplementation of a moderate amount of soybean oil (SO) or linseed oil (LO) in their diets without inducing negative effects on total dry matter intake (DMI). Furthermore, a direct comparison of the effects of SO vs. LO was made to determine the suitable plant oil in the diet of lactating buffaloes. The hypothesis tested was that dietary inclusion of plant oils could modify milk FA profile depending on whether linolenic acid (C18:3 n-3) or linoleic acid (C18:2 n-6) is the main polyunsaturated FA (PUFA), and that oil rich in C18:3 n-3 could increase n-3 PUFA and CLA in the milk of buffaloes.

\section{MATERIALS AND METHODS}

\section{Animals, Experimental Design, and Diets}

The experiment was performed at Buffalo Research Unit, Animal Production Department, Faculty of Agriculture, Menoufia University (Menoufia, Egypt). The location is at the latitude of $30.5503^{\circ} \mathrm{N}$ and $31.0106^{\circ}$ E. All the experimental procedures were approved by the Animal Ethics Committee (Menoufia University) and consistent with Egyptian rules for animal welfare. Eighteen multiparous Egyptian buffaloes (second to fourth parity) averaging $600 \pm 33 \mathrm{~kg}$ of body weight (BW), $96 \pm 13$ days in milk and producing $8.09 \pm 0.72 \mathrm{~kg}$

Table 1. Formulation and ingredient composition of experimental concentrates

\begin{tabular}{lccc}
\hline \multirow{2}{*}{\multicolumn{1}{c}{ Ingredient, g/kg DM }} & \multicolumn{3}{c}{ Concentrate $^{\mathrm{a}}$} \\
\cline { 2 - 4 } & CON & SO & LO \\
\hline Yellow corn, ground & 500 & 340 & 340 \\
Un-decorticated CSM & 170 & 170 & 170 \\
Soybean meal & 80 & 80 & 80 \\
Wheat bran & 220 & 300 & 300 \\
Soybean oil & - & 80 & - \\
Linseed oil & - & - & 80 \\
Limestone & 10 & 10 & 10 \\
Sodium bicarbonate & 10 & 10 & 10 \\
Sodium chloride & 7 & 7 & 7 \\
Mineral and vitamin mixture & 3 & 3 & 3 \\
\hline
\end{tabular}

Note: aRefers to experimental concentrates containing no additional oil $(\mathrm{CON})$, soybean oil (SO), or linseed oil (LO).

bMineral and vitamin mixture: provided per $\mathrm{kg}$ of concentrate including $5000 \mathrm{IU}$ of vitamin A, $2200 \mathrm{IU}$ of vitamin D3, 15 IU of vitamin $\mathrm{E}, 9.5 \mathrm{~g}$ of $\mathrm{K}, 2.4 \mathrm{~g}$ of $\mathrm{Mg} ; 2.1 \mathrm{~g}$ of $\mathrm{Na}, 3.4 \mathrm{~g}$ of $\mathrm{Cl}, 3.2 \mathrm{~g}$ of $\mathrm{S}, 0.16 \mathrm{mg}$ of $\mathrm{Co}, 100 \mathrm{mg}$ of $\mathrm{Cu}, 1.3 \mathrm{mg}$ of I, $64 \mathrm{mg}$ of $\mathrm{Mn}, 64 \mathrm{mg}$ of $\mathrm{Zn}, 64 \mathrm{mg}$ of Fe, and $0.45 \mathrm{mg}$ of Se. of milk/d, were blocked according to days in milk, milk yield, and BW into 3 groups of 6 buffaloes each. The experimental design was a randomized block design with 6 replicates per treatment. Dietary treatments consisted of three concentrate supplements containing no additional lipid (CON), soybean oil (SO), or linseed oil (LO). Dairy buffaloes were offered corn silage, clover hay (long-stem), and a cereal-based concentrate (forage to concentrate ratio of 70:30, on a DM basis). All buffaloes were fed a basal ration with $5 \mathrm{~kg} / \mathrm{d}$ a cereal-based concentrate (with or without oil). The concentrate was offered as equal meals at 05:00 AM and 17:00 PM. The level of oil included in the concentrate calculated as a percent to DMI was $2.6 \%$ (400 g/head/d, $25.6 \mathrm{~g} / \mathrm{kg}$ DMI). The ingredients, chemical, and fatty acid compositions of the feeds and concentrates used in the experiment are shown in Tables 1, 2, and 3. The supplemented oil, as a constituent of concentrate, was mixed well with wheat bran and then was mixed with the whole concentrate ingredients immediately before feeding. All lactating buffaloes were individually fed in accordance with the experimental treatments. The study was conducted for 8 weeks, involving the first 14 days as an adaptation period, and the next 6 weeks as a measurable period. Animals were housed in individual tie stalls with free access to water and were milked twice per day at 06:00 AM and 18:00 PM using portable milking machine.

\section{Measurements, Sample Collection, and Chemical Analysis}

At the end of the study, feed samples were taken for chemical analysis. Samples were subjected to proximate chemical analysis according to the procedures of AOAC (2005) for dry matter (DM), crude protein (CP), ether extract (EE), and ash. Neutral detergent fiber (NDF) was measured using the method described by Van Soest et al. (1991). The chemical analysis was expressed on DM basis. Dairy buffaloes were milked twice

Table 2. The chemical and fatty acid compositions of concentrates used in the experiment

\begin{tabular}{lccc}
\hline \multirow{2}{*}{ Item } & \multicolumn{3}{c}{ Concentrate $^{\mathrm{a}}$} \\
\cline { 2 - 4 } & CON & SO & LO \\
\hline Chemical composition, g/kg DM & & & \\
Dry matter & 900 & 912 & 913 \\
Crude protein & 184 & 183.5 & 184.2 \\
Metabolizable energy, MJ/kg & 12.36 & 13.57 & 13.71 \\
Neutral detergent fiber & 201.0 & 217.8 & 219.7 \\
Ether extract & 34.1 & 105.5 & 101.3 \\
Ash & 42.9 & 45.3 & 44.6 \\
Fatty acid composition, g/100g fatty acids & & \\
C16:0 & 13.93 & 15.49 & 14.95 \\
C18:0 & 1.56 & 2.07 & 2.13 \\
C18:1 & 23.50 & 24.37 & 24.26 \\
C18:2 n6 & 37.67 & 33.58 & 31.50 \\
C18:3 n3 & 7.43 & 9.17 & 13.50 \\
C20:0 & 0.41 & 0.43 & 0.38 \\
\hline
\end{tabular}

Note: ${ }^{\text {aRefers to experimental concentrates containing no additional oil }}$ $(\mathrm{CON})$, soybean oil $(\mathrm{SO})$, or linseed oil $(\mathrm{LO})$. 
Table 3. The chemical and fatty acid compositions of forages and oils used in the experiment

\begin{tabular}{|c|c|c|c|c|}
\hline \multirow[t]{2}{*}{ Item } & \multicolumn{2}{|c|}{ Forage } & \multicolumn{2}{|c|}{ Oil } \\
\hline & Corn silage & Clover hay & Soybean & Linseed \\
\hline \multicolumn{5}{|l|}{ Chemical composition, $\mathrm{g} / \mathrm{kg} \mathrm{DM}$} \\
\hline Dry matter & 353 & 880 & - & - \\
\hline Crude protein & 81.0 & 157.0 & - & - \\
\hline Metabolizable energy, MJ/kg & 11.30 & 9.60 & 35.15 & 36.82 \\
\hline Neutral detergent fiber & 450 & 520 & - & - \\
\hline Ether extract & 29.5 & 19.5 & 1000 & 1000 \\
\hline Ash & 51 & 80 & - & - \\
\hline \multicolumn{5}{|c|}{ Fatty acid composition, $\mathrm{g} / 100 \mathrm{~g}$ fatty acids } \\
\hline C16:0 & 22.07 & 16.68 & 12.44 & 5.71 \\
\hline $\mathrm{C} 18: 0$ & 9.54 & 10.77 & 4.95 & 5.72 \\
\hline C18:1 & 9.75 & 21.24 & 24.75 & 22.18 \\
\hline C18:2 n6 & 17.79 & 15.24 & 49.6 & 14.67 \\
\hline C18:3 n3 & 15.60 & 43.09 & 7.90 & 49.55 \\
\hline C20:0 & 1.1 & 0.39 & 0.33 & 0.16 \\
\hline
\end{tabular}

daily, and milk yields were recorded individually along 6 weeks. The collected milk samples for 2 consecutive days per week were analyzed for protein, lactose, fat, ash, and total solids concentrations using an ultrasonic milk analyzer (Lactoscan, Model MCC, Milk Analyzer, Bulgaria). Average daily yields (g/d) of milk components were calculated for each buffalo by multiplying milk production by the content of milk component ( $\mathrm{g} /$ $\mathrm{kg}$ ). The milk gross energy was calculated using the formula of Tyrell \& Reid (1965). Energy-corrected milk (ECM) was calculated using the equation of Sjaunja et al. (1991). The milk energy output (MJ/d) was calculated by multiplying milk energy $(\mathrm{MJ} / \mathrm{kg})$ by milk production $(\mathrm{kg} / \mathrm{d})$.

Milk samples were collected from individual buffaloes at the end of the experiment and stored at $-20^{\circ} \mathrm{C}$ until analyzed for FA composition. The FA composition was determined by conversion of oil to FA methyl esters by adding $\mathrm{n}$-hexane $(950 \mu \mathrm{L})$, oil $(50 \mathrm{mg})$ and sodium methoxide $(50 \mu \mathrm{L})$ according to Cocks \& Van Rede (1966) using a gas chromatograph (Model GC-14A, Shimadzu Corporation, Kyoto, Japan) equipped with a flame-ionization detector and a polar capillary column (BPX70, 0.25; SGE Incorporated, USA). The FA methyl esters peaks were recognized by comparing their retention times with the authentic FA methyl ester standards. The FA relative percent was calculated depending on the peak area of FA to the total peak area of all FA in the sample.

Blood samples from the jugular vein of each buffalo were collected at the end of the experiment into collection tubes (Venoject, Terumo Europe Ltd., Leuven, Belgium). Separations of serum from coagulant blood were conducted immediately within an hour by centrifugation for 15 minutes at $3000 \mathrm{rpm}$ (Multifuge IS-R, D-37520 Osterode, Germany). Collected serums were stored at $-20^{\circ} \mathrm{C}$ for further analysis. Total triglycerides, total lipids, high-density lipoprotein (HDL), LDL, alanine aminotransferase (ALT), and aspartate aminotransferase (AST) were measured as explained by Selim $\&$ Hussein (2020).

\section{Statistical Analysis}

Experimental data were analyzed by ANOVA using the Mixed procedure of SAS (version 9.2, SAS Institute, Cary, NC) with a model that included the buffalo as a random effect and week and treatment as fixed effects. Sums of squares for dietary treatments were then separated into a single degree of freedom contrasts to test their significances as follows: (1) plant oils in the diet (control vs. SO + LO), and (2) comparison of plant oil PUFA sources (SO vs. LO). Arithmetic means are reported, and treatment effects declared significant at $\mathrm{p}<0.05$. Data are expressed as mean \pm SEM.

\section{RESULTS}

\section{Dry Matter and Nutrient Intakes}

Dry matter, ME, CP, EE, NDF, and ash concentrations of corn silage and clover hay were normally in the ranges reported (Table 3 ). Corn silage was abundant in C16:0, while clover hay was rich in C18:3 n3 (Table 3). Soybean oil was rich in C18:2 n6, whereas LO was high in C18:3 n3 (Table 3). Buffaloes consumed all the concentrates fed. Total DMI, forage intake, and NDF intake was not altered by the dietary inclusion of SO or LO in concentrate supplements comprising approximately $2.6 \%$ of the diet DM $(400 \mathrm{~g} / \mathrm{head} / \mathrm{d}$ or $25.6 \mathrm{~g} / \mathrm{kg} \mathrm{DM})$ (Table 4).

\section{Milk Yield and Composition}

Daily yields of milk, fat, protein, and lactose were not altered by experimental treatments (Table 4). The dietary SO or LO inclusion at $400 \mathrm{~g} / \mathrm{d}$ or $25.6 \mathrm{~g} / \mathrm{kg}$ DMI had no effect on milk yield (Table 4 ). Milk protein $(p<0.01)$, lactose $(p<0.01)$, ash $(p<0.05)$, and total solids $(\mathrm{p}<0.01)$ concentrations were strongly affected by LO supplementation (Table 4 ), characterized by greater values compared to those of the control group. There was no significant difference in milk composition between 
Table 4. Nutrient intakes, milk production, and milk composition of dairy buffaloes treated by soybean oil or linseed oil

\begin{tabular}{|c|c|c|c|c|c|c|}
\hline \multirow{2}{*}{ Variables $^{c}$} & \multicolumn{3}{|c|}{ Treatments $^{\mathrm{a}}$} & \multirow{2}{*}{ SEM } & \multicolumn{2}{|c|}{ Significance $^{\mathrm{b}}$} \\
\hline & $\mathrm{CON}$ & $\mathrm{SO}$ & $\mathrm{LO}$ & & CON vs. others & SO vs. LO \\
\hline \multicolumn{7}{|l|}{ Intake } \\
\hline Dry matter, kg/d & 15.80 & 15.65 & 15.70 & 0.39 & 0.84 & 0.86 \\
\hline Corn silage, kg DM/d & 6.20 & 6.15 & 6.20 & 0.34 & 0.75 & 0.76 \\
\hline Clover hay, kg DM/d & 4.60 & 4.50 & 4.50 & 0.20 & 0.94 & 0.99 \\
\hline Metabolizable energy, MJ/d & 176.11 & 180.55 & 181.81 & 4.53 & 0.44 & 0.65 \\
\hline Neutral detergent fiber, $\mathrm{kg} / \mathrm{d}$ & 6.19 & 6.20 & 6.23 & 0.18 & 0.54 & 0.69 \\
\hline \multicolumn{7}{|l|}{ Yield } \\
\hline Milk yield, kg/d & 8.37 & 8.25 & 8.04 & 0.28 & 0.53 & 0.75 \\
\hline $\mathrm{ECM}, \mathrm{kg} / \mathrm{d}$ & 13.76 & 12.53 & 13.93 & 0.817 & 0.26 & 0.29 \\
\hline Milk fat, g/d & 782.35 & 678.19 & 788.28 & 51.52 & 0.13 & 0.16 \\
\hline Milk protein, g/d & 303.05 & 302.40 & 307.82 & 13.45 & 0.86 & 0.97 \\
\hline Milk lactose, g/d & 349.10 & 354.96 & 357.91 & 16.30 & 0.86 & 0.98 \\
\hline \multicolumn{7}{|l|}{ Concentration in milk } \\
\hline Total solids, \% & $17.88^{\mathrm{ab}}$ & $16.97^{b}$ & $18.87^{a}$ & 0.406 & 0.009 & 0.003 \\
\hline Fat, $\%$ & $9.34^{\mathrm{ab}}$ & $8.20^{\mathrm{b}}$ & $9.80^{\mathrm{a}}$ & 0.33 & 0.008 & 0.007 \\
\hline Protein, \% & $3.62^{\mathrm{b}}$ & $3.67^{b}$ & $3.82^{\mathrm{a}}$ & 0.027 & 0.003 & 0.01 \\
\hline Lactose, $\%$ & $4.17^{\mathrm{b}}$ & $4.30^{\mathrm{ab}}$ & $4.45^{\mathrm{a}}$ & 0.06 & 0.004 & 0.05 \\
\hline Ash, $\%$ & $0.75^{\mathrm{b}}$ & $0.77^{\mathrm{ab}}$ & $0.80^{\mathrm{a}}$ & 0.01 & 0.04 & 0.05 \\
\hline Milk energy content, MJ/kg & $5.11^{\mathrm{ab}}$ & $4.72^{\mathrm{b}}$ & $5.39^{a}$ & 0.145 & 0.01 & 0.009 \\
\hline Milk energy output, MJ/d & 42.83 & 38.97 & 43.36 & 2.562 & 0.26 & 0.28 \\
\hline \multicolumn{7}{|l|}{ Milk efficiency } \\
\hline Milk/DMI & 0.547 & 0.545 & 0.529 & 0.019 & 0.60 & 0.43 \\
\hline ECM/DMI & 0.90 & 0.82 & 0.91 & 0.053 & 0.25 & 0.14 \\
\hline
\end{tabular}

Note: aRefers to experimental concentrates containing no additional oil (CON), soybean oil (SO), or linseed oil (LO).

bSignificance of effects due to plant oil in the diet (CON vs. SO and LO); source of PUFA in the diet (SO vs. LO); Means in the same row with different superscripts differ significantly $(\mathrm{p}<0.05)$; $\mathrm{SEM}=$ standard error of the mean.

${ }^{\mathrm{D}} \mathrm{DMI}=$ dry matter intake; $\mathrm{ECM}=$ energy corrected milk. Milk energy content $(\mathrm{MJ} / \mathrm{kg})=4.184 \times[(41.63 \times \mathrm{fat}(\mathrm{g} / \mathrm{kg})+24.13 \times \mathrm{protein}(\mathrm{g} / \mathrm{kg})+21.60 \times$ lactose $(\mathrm{g} / \mathrm{kg})-117.2) / 10000] \times 2.204$ according to Tyrell \& Reid $(1965)$. ECM $(\mathrm{kg} / \mathrm{d})=\operatorname{milk}(\mathrm{kg} / \mathrm{d}) \times[38.3 \times \mathrm{fat}(\mathrm{g} / \mathrm{kg})+24.2 \times \mathrm{protein}(\mathrm{g} / \mathrm{kg})+16.54$ $\times$ lactose $(\mathrm{g} / \mathrm{kg})+20.7 \mathrm{~J} / 3140$ according to Sjaunja et al. $(1991)$

SO and control. The LO supplementation significantly increased $(\mathrm{p}<0.01)$ milk lactose percentage $(4.45 \%$ vs. $4.17 \%$ ) compared to control (Table 4).

\section{Milk Fatty Acid Profile}

Data of milk fatty acids composition is presented in Table 5. Compared with the control group, buffaloes fed diets supplemented with LO or SO led to the increase in the milk fat concentrations of $\mathrm{C} 4: 0$ and $\mathrm{C} 6: 0$, and decrease C10:0, C12:0, C14:0, and C16:0 ( $p<0.001)$. An increased milk fat $\mathrm{C} 18: 0(\mathrm{p}<0.001)$ was also observed as the buffaloes were fed diets containing LO or SO diets compared to those fed the control diet (Table 5). The animals supplemented with LO or SO at a level of 400 $\mathrm{g} / \mathrm{d}$ resulted in greater C18:2, C18:1, and C20:0 $(\mathrm{p}<0.001)$ than those fed the control diet. Milk fat concentration of $\mathrm{C} 18: 3$ was reported to be higher $(\mathrm{p}<0.001)$ in the LO group than the other groups. There was a tendency $(\mathrm{p}=$ 0.05) of higher C20:1 concentration in the milk fat of buffaloes fed a diet supplemented with LO than those fed the control diet.

Milk samples obtained from SO- or LOsupplemented buffaloes with high n6- FA and CLA concentrations were also characterized by low atherogenicity index (lower index by about $24.19 \%$ and $47.65 \%$ for
SO and LO, respectively compared to control $(\mathrm{p}<0.001)$. Buffaloes fed LO had reduced milk SFA (59.73\% vs. 66.70 and $68.59 \%$ for SO and control, respectively) and improved milk PUFA (6.03\%) compared to the SO and control groups (2.53 and $2.93 \%$, respectively), which was associated with the increasing PUFA to SFA ratio $(p<0.001)$. The percentage of total MUFA obviously increased $(\mathrm{p}<0.001)$ as the level of LO or SO included up to $400 \mathrm{~g} / \mathrm{d}$ that resulted in an increase $(\mathrm{p}<0.001)$ in the milk fat MUFA:SFA of these buffaloes. The greater total proportion of n-3 FA in the milk fat of lactating buffaloes fed diets supplemented with LO led to a decrease in the ratio of $n-6$ to $n-3$ FA milk fat $(p<0.001)$. However, a higher proportion of total n-6 FA in the milk fat of the animals fed SO led to an increase of n-6:n3 FA in the milk fat of these buffaloes $(\mathrm{p}<0.001)$.

\section{Blood Lipid Profile and Hepatoprotective Activity}

Buffaloes fed diets containing $400 \mathrm{~g} / \mathrm{d}$ of $\mathrm{SO}$ showed a greater total cholesterol level $(p<0.05)$ in the serum than those fed the $\mathrm{CON}$ diets (Table 6). A trend for higher serum total lipids $(p=0.05)$ and LDL $(p=0.08)$ was recorded in the buffaloes fed SO than those fed the CON diet (Table 6). There were no significant differences in serum total lipids, cholesterol, HDL, and LDL 
Table 5. Milk fatty acids composition (g/100 g fatty acids) of dairy buffaloes treated by soybean oil or linseed oil

\begin{tabular}{|c|c|c|c|c|c|c|}
\hline \multirow{2}{*}{ Fatty acidsc } & \multicolumn{3}{|c|}{ Treatments ${ }^{a}$} & \multirow{2}{*}{ SEM } & \multicolumn{2}{|c|}{ Significance $^{\mathrm{b}}$} \\
\hline & $\mathrm{CON}$ & SO & LO & & CON vs. others & SO vs. LO \\
\hline C4:0 & $0.07^{c}$ & $0.48^{\mathrm{a}}$ & $0.29^{b}$ & 0.005 & $<0.001$ & $<0.001$ \\
\hline C6:0 & $0.30^{c}$ & $0.72^{\mathrm{a}}$ & $0.59^{\mathrm{b}}$ & 0.008 & $<0.001$ & $<0.001$ \\
\hline C8:0 & 0.38 & 0.44 & 0.37 & 0.049 & 0.37 & 0.38 \\
\hline C10:0 & $1.11^{\mathrm{a}}$ & $0.94^{\mathrm{b}}$ & $0.75^{c}$ & 0.032 & $<0.001$ & 0.003 \\
\hline C12:0 & $1.80^{\mathrm{a}}$ & $1.50^{\mathrm{b}}$ & $1.20^{c}$ & 0.024 & $<0.001$ & $<0.001$ \\
\hline C14:0 & $10.12^{\mathrm{a}}$ & $8.06^{\mathrm{b}}$ & $6.56^{c}$ & 0.244 & $<0.001$ & 0.002 \\
\hline$\sum \mathrm{C} 14: 1$ & 0.613 & 0.520 & 0.407 & 0.332 & 0.82 & 0.94 \\
\hline C16:0 & $35.87^{a}$ & $30.43^{b}$ & $23.57^{c}$ & 1.045 & $<0.001$ & 0.001 \\
\hline$\sum \mathrm{C} 16: 1$ & $0.04^{\mathrm{a}}$ & $0.01^{\mathrm{b}}$ & $0.05^{\mathrm{a}}$ & 0.003 & $<0.001$ & $<0.001$ \\
\hline $\mathrm{C} 17: 0$ & $0.97^{a}$ & $0.87^{a}$ & $0.71^{\mathrm{b}}$ & 0.034 & 0.001 & 0.008 \\
\hline C18:0 & $15.29^{c}$ & $19.94^{\mathrm{b}}$ & $21.61^{\mathrm{a}}$ & 0.212 & $<0.001$ & 0.001 \\
\hline$\sum$ cis $\mathrm{C} 18: 1$ & 3.56 & 3.28 & 3.93 & 0.219 & 0.57 & 0.33 \\
\hline$\sum$ trans C18:1 & $23.81^{\mathrm{c}}$ & $26.48^{b}$ & $29.29^{a}$ & 0.476 & $<0.001$ & 0.001 \\
\hline$\sum \mathrm{C} 18: 1$ & $27.37^{c}$ & $29.76^{\mathrm{b}}$ & $33.22^{\mathrm{a}}$ & 0.588 & $<0.001$ & 0.003 \\
\hline C18:2 & $1.75^{\mathrm{c}}$ & $2.07 \mathrm{~b}$ & $2.78^{a}$ & 0.098 & $<0.001$ & 0.001 \\
\hline CLA (conjugated linoleic acid) & $0.35^{c}$ & $0.49^{\mathrm{b}}$ & $0.55^{\mathrm{a}}$ & 0.021 & 0.001 & 0.002 \\
\hline $\mathrm{C} 18: 3$ & $1.18^{\mathrm{b}}$ & $0.46^{c}$ & $3.25^{\mathrm{a}}$ & 0.041 & $<0.001$ & $<0.001$ \\
\hline C20:0 & $2.68^{c}$ & $3.32^{\mathrm{b}}$ & $4.08^{\mathrm{a}}$ & 0.065 & $<0.001$ & $<0.001$ \\
\hline$\sum \mathrm{C} 20: 1$ & 0.17 & 0.29 & 0.32 & 0.060 & 0.05 & 0.82 \\
\hline \multicolumn{7}{|l|}{ Summary } \\
\hline$\sum$ SFA & $68.59^{a}$ & $66.70^{\mathrm{a}}$ & $59.73^{\mathrm{b}}$ & 1.721 & 0.005 & 0.007 \\
\hline$\sum$ MUFA & $28.19^{c}$ & $30.57 \mathrm{~b}$ & $33.99^{a}$ & 0.409 & $<0.001$ & $<0.001$ \\
\hline$\sum$ PUFA & $2.93^{\mathrm{b}}$ & $2.53^{\mathrm{b}}$ & $6.03^{a}$ & 0.139 & $<0.001$ & $<0.001$ \\
\hline MUFA/SFA & $0.41^{c}$ & $0.46^{\mathrm{b}}$ & $0.59^{a}$ & 0.007 & $<0.001$ & $<0.001$ \\
\hline PUFA/SFA & $0.043^{b}$ & $0.038^{\mathrm{b}}$ & $0.100^{\mathrm{a}}$ & 0.001 & $<0.001$ & $<0.001$ \\
\hline $\mathrm{n} 6 / \mathrm{n} 3$ & $1.48^{\mathrm{b}}$ & $4.52^{\mathrm{a}}$ & $0.855^{c}$ & 0.111 & $<0.001$ & $<0.001$ \\
\hline \multicolumn{7}{|c|}{ Estimated $\Delta 9$-desaturase activity (Fatty acid ratios) } \\
\hline C14:1:C14:0 & 0.061 & 0.066 & 0.063 & 0.040 & 0.99 & 0.98 \\
\hline C16:1:C16:0 & $0.001^{\mathrm{b}}$ & $0.0003^{\mathrm{b}}$ & $0.002^{\mathrm{a}}$ & 0.0002 & $<0.001$ & $<0.001$ \\
\hline Atherogenicity index & $2.77^{a}$ & $2.10^{\mathrm{b}}$ & $1.45^{c}$ & 0.045 & $<0.001$ & $<0.001$ \\
\hline
\end{tabular}

Note: aRefers to experimental concentrates containing no additional oil (CON), soybean oil (SO), or linseed oil (LO).

bSignificance of effects due to plant oil in the diet (CON vs. SO and LO); source of PUFA in the diet (SO vs. LO); Means in the same row with different superscripts differ significantly $(\mathrm{p}<0.05)$; SEM= standard error of the mean.

'CLA, conjugated linoleic acid (trans-10, cis-12 C18:2 and cis-9, trans-11 C18:2); SFA, saturated fatty acids; MUFA, monounsaturated fatty acids; PUFA, polyunsaturated fatty acids.

Table 6. Blood biochemical constituents of dairy buffaloes treated by soybean oil or linseed oil

\begin{tabular}{|c|c|c|c|c|c|c|}
\hline \multirow{2}{*}{ Variables $^{c}$} & \multicolumn{3}{|c|}{ Treatments $^{\mathrm{a}}$} & \multirow{2}{*}{ SEM } & \multicolumn{2}{|c|}{ Significance $^{\mathrm{b}}$} \\
\hline & $\mathrm{CON}$ & SO & LO & & CON vs. others & SO vs. LO \\
\hline Total triglycerides, mg/dL & 23.76 & 26.48 & 24.50 & 2.275 & 0.50 & 0.67 \\
\hline Total lipids, mg/dL & $319.23^{b}$ & $412.82^{\mathrm{a}}$ & $355.13^{\mathrm{ab}}$ & 29.151 & 0.05 & 0.20 \\
\hline Cholesterol, mg/dL & $175.45^{\mathrm{b}}$ & $257.05^{a}$ & $212.50^{\mathrm{b}}$ & 12.856 & 0.002 & 0.03 \\
\hline $\mathrm{HDL}, \mathrm{mg} / \mathrm{dL}$ & 104.23 & 114.84 & 105.77 & 9.417 & 0.51 & 0.62 \\
\hline $\mathrm{LDL}, \mathrm{mg} / \mathrm{dL}$ & 103.28 & 146.21 & 134.39 & 15.767 & 0.08 & 0.74 \\
\hline AST, U/L & 57.00 & 59.50 & 55.60 & 1.633 & 0.53 & 0.12 \\
\hline ALT, U/L & 36.90 & 38.60 & 34.60 & 1.352 & 0.65 & 0.33 \\
\hline
\end{tabular}

Note: a Refers to experimental concentrates containing no additional oil (CON), soybean oil (SO), or linseed oil (LO).

bSignificance of effects due to plant oil in the diet (CON vs. SO and LO); source of PUFA in the diet (SO vs. LO); Means in the same row with different superscripts differ significantly $(\mathrm{p}<0.05)$; SEM= standard error of the mean.

cHDL= high-density lipoprotein; LDL= low-density lipoprotein; AST= aspartate aminotransferase; ALT= alanine aminotransferase. 
between the LO-supplemented group and the control group (Table 6). Serum liver enzymes, including AST and ALT, were not altered by the treatments (Table 6).

\section{DISCUSSION}

\section{Dry Matter and Nutrient Intakes}

In the current study, total DMI, forage intake, and NDF intake were not different by the relatively moderate inclusion of $\mathrm{SO}$ or $\mathrm{LO}$ in concentrate supplements. These findings are in accordance with the most literature reports (Dirandeh et al., 2013; Mach et al., 2013; Suksombat et al., 2016) that showed slight effects of type and concentration of lipid supplement on DMI when its inclusion level was below $6 \%$ of DM. Meanwhile, at greater inclusion levels, plant oils may persuade adverse effects on DMI (Huhtanen et al., 2008), but not in all situations (Shingfield et al., 2008). Martin et al. (2008) and Lerch et al. (2012) reported that dairy cows fed with a diet supplemented with LO $(5.7 \%$ or 3\% DMI, respectively) in the basal diet had lower DMI. A recent study by Suksombat et al. (2016) concluded that supplementation of lactating dairy cows with LO at $2.9 \% \mathrm{DM}$ in the basal diet $(500 \mathrm{~g} / \mathrm{d})$ maintaining a 56:44 roughage to concentrate ratio did not alter feed and nutrient intakes. The meta-analysis by Mahdavi et al. (2019) showed that DMI was reduced as a result of SO supplementation in the diets of dairy cows. In the present study, buffaloes were fed LO or SO at about $25.6 \mathrm{~g} / \mathrm{kg}$ of DMI $(400 \mathrm{~g} /$ head/d), may not be high enough to reduce DM and nutrient intakes. Furthermore, the lack of variations in DMI suggested that feed palatability was not altered by LO or SO inclusion. Unfortunately, there is no any previous researches on the effects of the dietary inclusion of LO or SO on DMI of lactating buffaloes to compare with the findings reported herein. The reduction in DMI of dairy cows fed plant oils, such as LO, SO, fish oil or sunflower oil, have been attributed to the detrimental effects of unsaturated FA on rumen microorganisms causing a decrease of ruminal fiber digestibility and increase of cholecystokinin and glucagon-like peptide 1 activities (Jenkins \& Harvatine, 2014; Kairenius et al., 2018; Mahdavi et al., 2019).

\section{Milk Yield and Composition}

The impacts of oil supplements on milk yield are different and known to be affected by the inclusion level of fat, degree of unsaturation, and diet composition (Halmemies-Beauchet-Filleau et al., 2011; Suksombat et al., 2014 \& 2016). Successful SO or LO inclusion at 400 $\mathrm{g} / \mathrm{d}$ or $25.6 \mathrm{~g} / \mathrm{kg}$ DMI had no effect on milk production in the present study. Likewise, unaffected milk production was reported in dairy cows fed LO-supplemented diet at $500 \mathrm{~g} / \mathrm{d}$ (Suksombat et al., 2014 \& 2016). However, very recent studies on lactating goats (Kholif et al., 2016 \& 2018) and dairy cows (Mahdavi et al., 2019) revealed an increase in milk yield as a result of SO supplementation. They attributed this increase in milk production to the enhanced nutrient digestion and ruminal fermentation, as well as the increased energy density and energy intake. In contrast, supplementation of $800 \mathrm{~g} / \mathrm{d}$ fish oil + LO at a ratio of 1:3 (w/w) (Brown et al., 2008) or 5.7\% LO or extruded linseed to corn silage-based diet of dairy cows (Martin et al., 2008) had reduced milk production. The depression of DMI and/or nutrient digestibility (especially fiber) as a result of disturbances in rumen function, rumen fermentation, and a shift of the digestion site from the rumen to the intestine triggered by a high dietary intake of lipids (i.e., $>5 \%$ of DMI) were the main reasons for the reduced milk yield (Brown et al., 2008; Martin et al., 2008). In the current study, moderate amounts of LO or SO in the diet $(400 \mathrm{~g} / \mathrm{head} / \mathrm{d} ; 25.6 \mathrm{~g} / \mathrm{kg}$ DM; $2.6 \%$ DMI) did not affect DM or nutrient intakes, which may contribute to the unchanged milk yield.

In the present study, milk fat concentration was not altered by dietary LO or SO supplementation. On the other hand, many recent studies (Kholif et al., 2016 \& 2018; Mahdavi et al., 2019) recorded a reduction in the milk fat percent as a result of SO supplementation due to a decrease of fiber digestion and thus ruminal acetate production. Angulo et al. (2012) reported that dairy cows fed with a diet supplemented with $3.1 \%$ $\mathrm{LO}+$ docosahexaenoic acid Gold algae or sunflower oil + docosahexaenoic acid Gold algae, compared to those fed a control diet with $3.1 \%$ protected saturated fat, had decreased milk fat. A reduction of milk fat is more probably occurred with the inclusion of non-protected fat in corn silage-based diet, but this reduction was minimized with the other forages, particularly alfalfa hay (Halmemies-Beauchet-Filleau et al., 2011). Furthermore, the decreased milk fat percent in some other previously reported studies was triggered by the reduced DMI and fiber digestion, because of the elevated level of ingested LO (Martin et al., 2008) and the decreased lipogenesis in the mammary gland (Chilliard et al., 2007).

Regarding milk lactose, LO supplementation increased milk lactose percentage. This would be a result of the augmented propionate production since it is the precursor for gluconeogenesis and lactose synthesis (Boerman \& Lock 2014; Kholif et al., 2018; Vargas et al., 2020). Milk lactose percent was not affected by SO supplementation, which agreed with the results reported by Mahdavi et al. (2019). Milk protein percentage was increased in LO, while there was no difference in daily yield of protein $\mathrm{g} / \mathrm{d}$ between the treatment groups. Similarly, Gagliostro et al. (2015) observed the same findings when a blend of $\mathrm{SO}$ and $\mathrm{LO}$ was included in the diets of dairy buffaloes. On the other hand, the protein percentage was not affected by LO supplementation (Suksombat et al., 2014 \& 2016). The effect of plant oils on milk protein percentage has been variable. Inconsistency between studies in milk protein content in response to LO supplementation may be elucidated by the inclusion level of LO in the diet and the composition of the basal diet (Suksombat et al., 2014 \& 2016; Gagliostro et al., 2015).

\section{Milk Fatty Acid Profile}

The mammary gland is responsible for de novo synthesis for all C4:0 to C12:0, most of the 14:0, and half of 16:0 secreted in milk, whereas long-chain FA is 
originated from the diet or adipose tissue (Chilliard et al., 2007). Lactating buffaloes fed SO or LO diets had lower milk fat concentrations of C10:0, C12:0, C14:0, and C16:0, while greater milk fat content of C4:0 and C6:0. These findings revealed the less de novo FA synthesis appeared with lactating buffaloes fed LO and SO diets. Consequently, feeding high PUFA plant oils are commonly associated with the decreased de novo shortand medium-chain FA synthesis (Brown et al. 2008; Halmemies-Beauchet-Filleau et al., 2011; Lerch et al. 2012; Suksombat et al., 2016; Kholif et al., 2016 \& 2018). This reduction may be attributed to the suppressing effects of long-chain FA on the activity of mammary gland lipogenic enzymes such as acetyl-CoA carboxylase and the de novo synthesis of SFA in the mammary gland (Halmemies-Beauchet-Filleau et al., 2011; Suksombat et al., 2016). This is a vital issue from the point of view in animal nutrition. A reduction in milk contents of C14:0 and C16:0 from SO- and LO- buffaloes may be an optimistic target from a human health viewpoint since greater proportions of C12:0, C14:0, and C16:0 have been reported to be responsible for elevated plasma levels of cholesterol and LDL and the incidence of cardiovascular problems in humans consuming such FA (Simopoulos, 2016).

The observed increase in the milk fat $\mathrm{C} 18: 0$ as lactating buffaloes was fed diets containing $\mathrm{LO}$ or SO in the current study, indicating that greater ruminal biohydrogenation of UFA in buffaloes fed LO followed by the SO diet than in buffaloes fed the control diet (McKain et al., 2010; Suksombat et al., 2016). The increase of milk contents of n-3 FA, predominantly C18:3, and CLA in the buffaloes fed the LO diet in the present study, was in line with the magnitude responses reported in the other studies (Lerch et al., 2012; Mach et al. 2013; Suksombat et al., 2016). On the contrary, Lock \& Garnsworthy (2002) observed that plant oils rich in n-6 FA (e.g., SO) was more potential in the enrichment of CLA in the milk fat than oils rich in n-3 FA (e.g., LO). Enrichment of CLA concentration in milk was reported to be derived from incomplete biohydrogenation of linoleic acid by the rumen resulting an increase in the supply of C18:1 trans 11 for desaturation in the mammary gland or from endogenous synthesis from vaccenic acid via $\Delta^{9}$-desaturase activity in the mammary gland (Shingfield et al., 2008; Halmemies-Beauchet-Filleau et al., 2011). The endogenous synthesis of CLA in the mammary gland is considered as the main pathway in lactating cows (Shingfield et al., 2008; Halmemies-Beauchet-Filleau et al., 2011). Milk obtained from LO-supplemented buffaloes had greater n3- FA, CLA concentration, and lower atherogenicity index, suggesting that the consumption of its milk and dairy products has less harmful impacts regarding the atherosclerosis problems, being beneficially healthier for humans (Kholif et al., 2016; Suksombat et al., 2016).

Lactating buffaloes fed the LO diet had lower milk SFA and greater milk PUFA and n-3 FA, which was associated with the increasing ratio of PUFA to SFA and the decreasing ratio of n-6 to n-3 FA. However, a greater total n-6 FA in the milk fat of the buffaloes fed SO caused an increase in the ratio of n- 6 to n3 FA milk fat of these buffaloes. These findings were in agreement with recent studies (Halmemies-Beauchet-Filleau et al., 2011; Lerch et al., 2012; Kholif et al., 2016; Suksombat et al., 2016), which reported similar responses in milk FA profile when plant oils were used in dairy cows or goats. Mahdavi et al. (2019) reported that SO supplementation had no effect on C18:3 n-3 in milk fat because of its low concentration in SO. Although both of n-3 and n-6 FA are essential and have valuable impacts on human health, excessive levels of n-6 FA and very low levels of n-3 FA (increased n-6 to n-3 ratio) possibly interfering the way of the body to utilize n-3 FA and therefore limit their abundant health benefits (Simopoulos, 2016). LO supplementation could lower the ratio of $n-6$ to n-3 more than SO supplementation (Antonacci et al., 2018). The ratio of $n 6$ to $n-3$ is desirable to be closer to 2:1 (Benbrook et al., 2013). Lowering n-6 to n3 FA ratio in milk and dairy products has been recommended to decrease the incidence of certain diseases in humans (Simopoulos, 2016).

\section{Blood Lipid Profile and Hepatoprotective Activity}

All measured blood metabolites were within the normal values, as reported by Abd Ellah et al. (2013). Dietary supplementation of oils had no detrimental impacts on liver function, as serum ALT and AST levels were not altered by the dietary treatments. The current findings are in consistent with the results reported by Kholif et al. (2016). Feeding oils did not alter blood triglyceride concentration in lactating dairy cows (Ye et al., 2009) and dairy goats (Kholif et al., 2016). Feeding oil are known to increase the energy density of the diet and energy intake, which in turn changes lipid metabolism in animal tissues. The current findings showed a tendency towards higher serum total lipids and LDL concentrations without affecting triglycerides, suggesting that lipid supplementation triggered the elevated levels of blood triglyceride-rich lipoproteins (Kholif et al., 2016) since LDL is responsible for cholesterol transportation. Similarly, Ye et al. (2009) observed that feeding SO and LO to lactating dairy cows increased plasma LDL concentration.

\section{CONCLUSION}

Supplementing lactating buffalo diets-based on corn silage and clover hay with LO up to $400 \mathrm{~g} / \mathrm{d}$ could augment the nutritive value of milk with valuable FA (n-3 FA, MUFA, and CLA) and reduce atherogenicity index and n-6 to n-3 FA ratio without triggering any adverse effects on milk yield, milk composition or buffalo performance.

\section{CONFLICT OF INTEREST}

The authors declare that there is no conflict of interest with any financial, personal, or other relationships with other people or organization related to the material discussed in the manuscript. 


\section{ACKNOWLEDGEMENT}

The authors gratefully acknowledge the contribution of staff at the University of Menoufia Buffalo Research Farm in Shibin El-kom for the care of experimental animals. Authors are thankful to the Department of Animal Production, Faculty of Agriculture, Menoufia University (Menoufia, Egypt) and Department of Nutrition and Clinical Nutrition, Faculty of Veterinary Medicine, Menoufia University (Menoufia, Egypt) for providing the financial support and research facilities.

\section{REFERENCES}

Abd Ellah, M. R., M. I. Hamed, \& R. I. Derar. 2013. Serum biochemical and haematological reference values for midterm pregnant buffaloes. J. Appl. Anim. Res. 41:309-317. https:// doi.org/10.1080/09712119.2013.782870

Angulo, J., B. Hiller, M. Olivera, L. Mahecha, D. Dannenberger, G. Nuernberg, B. Losand, \& K. Nuernberg. 2012. Dietary fatty acid intervention of lactating cows simultaneously affects lipid profiles of meat and milk. J. Sci. Food Agric. 92:2968-2974. https://doi.org/10.1002/jsfa.5709

Antonacci, L. E., M. Bussetti, M. A. Rodriguez, A. V. Cano, \& G. A. Gagliostro. 2018. Effect of diet supplementation with combinations of soybean and linseed oils on milk production and fatty acid profile in lactating dairy ewes. Agric. Sci. 9:200-220. https://doi.org/10.4236/as.2018.92015

AOAC. 2005. Official Methods of Analysis of AOAC International. Assoc. Off. Anal. Chem., Arlington.

Benbrook, C. M., G. Butler, M. A. Latif, C. Leifert, \& D. R. Davis. 2013. Organic production enhances milk nutritional quality by shifting fatty acid composition: a United States-wide, 18-month study. PloS One. 8:e82429. https:// doi.org/10.1371/journal.pone.0082429

Boerman, J. \& A. Lock. 2014. Effect of unsaturated fatty acids and triglycerides from soybeans on milk fat synthesis and biohydrogenation intermediates in dairy cattle. J. Dairy Sci. 97:7031-7042. https://doi.org/10.3168/jds.2014-7966

Brown, W., A. A. AbuGhazaleh, \& S. A. Ibrahim. 2008. Milk conjugated linoleic acid response to fish oil and linseed oil supplementation of grazing dairy cows. AsianAustralas. J. Anim. Sci. 21:663-670. https://doi.org/10.5713/ ajas.2008.70272

Chilliard, Y., F. Glasser, A. Ferlay, L. Bernard, J. Rouel, \& M. Doreau. 2007. Diet, rumen biohydrogenation and nutritional quality of cow and goat milk fat. Eur. J. Lipid Sci. Technol. 109:828- 855. https://doi.org/10.1002/ ejlt.200700080

Cocks, L. V. \& C. Van Rede. 1966. Laboratory handbook for oil and fats analysts. Academic Press, London, $\mathrm{p} 88$.

Dirandeh, E., A. Towhidi, S. Zeinoaldini, M. Ganjkhanlou, Z. Ansari Pirsaraei, \& A. Fouladi-Nashta. 2013. Effects of different polyunsaturated fatty acid supplementations during the postpartum periods of early lactating dairy cows on milk yield, metabolic responses, and reproductive performances. J. Anim. Sci. 91:713-721. https://doi. org/10.2527/jas.2012-5359

El-Salam, M. A. \& S. El-Shibiny. 2011. A comprehensive review on the composition and properties of buffalo milk. Dairy Sci. Technol. 91:663-699. https://doi.org/10.1007/ s13594-011-0029-2

Gagliostro, G. A., E. M. Patiño, M. Sanchez Negrette, G. Sager, L. Castelli, L. E. Antonacci, F. Raco, L. Gallello, M. A. Rodríguez, C. Cañameras, M. L. Zampatti, \& C. Bernal. 2015. Milk fatty acid profile from grazing buffaloes fed a blend of soybean and linseed oils. Arq. Bras. Med. Vet.
Zootec. 67:927-934. https://doi.org/10.1590/1678-4162-7811

Halmemies-Beauchet-Filleau, A., T. Kokkonen, A. M. Lampi, V. Toivonen, K. J. Shingfield, \& A. Vanhatalo. 2011. Effect of plant oils and camelina expeller on milk fatty acid composition in lactating cows fed diets based on red clover silage. J. Dairy Sci. 94:4413-4430. https://doi.org/10.3168/ jds.2010-3885

Huhtanen, P., M. Rinne, \& J. Nousiainen. 2008. Evaluation of concentrate factors affecting silage intake of dairy cows: A development of the relative total diet intake index. Animal. 2:942-953. https://doi.org/10.1017/S1751731108001924

IDF. 2010. The World Dairy Situation 2010. Bulletin of the IDF No. 446/2010. International Dairy Federation, Brussels, Belgium.

Jenkins, T. C. \& K. J. Harvatine. 2014. Lipid feeding and milk fat depression. Vet. Clin. Food Anim. Pract. 30:623-642. https://doi.org/10.1016/j.cvfa.2014.07.006

Kairenius, P., H. Leskinen, V. Toivonen, S. Muetzel, S. Ahvenjärvi, A. Vanhatalo, P. Huhtanen, R. J. Wallace, \& K. J. Shingfield. 2018. Effect of dietary fish oil supplements alone or in combination with sunflower and linseed oil on ruminal lipid metabolism and bacterial populations in lactating cows. J. Dairy Sci. 101:1-15. https://doi.org/10.3168/ jds.2017-13776

Kholif, A. E., T. A. Morsy, \& M. M. Abdo. 2018. Crushed flaxseed versus flaxseed oil in the diets of Nubian goats: Effect on feed intake, digestion, ruminal fermentation, blood chemistry, milk production, milk composition and milk fatty acid profile. Anim. Feed Sci. Tech. 244:66-75. https:// doi.org/10.1016/j.anifeedsci.2018.08.003

Kholif, A. E., T. A. Morsy, A. M. Abd El Tawab, U.Y. Anele, \& M. L. Galyean. 2016. Effect of supplementing diets of Anglo-Nubian goats with soybean and flaxseed oils on lactational performance. J. Agric. Food Chem. 64:6163-6170. https://doi.org/10.1021/acs.jafc.6b02625

Lerch, S., Ferlay, A., D. Pomiès, B. Martin, J. A. A. Pires, \& Y. Chilliard. 2012. Rapeseed or linseed supplements in grassbased diets: Effects on dairy performance of Holstein cows over 2 consecutive lactations. J. Dairy Sci. 95:1956-1970. https://doi.org/10.3168/jds.2011-4575

Lock, A. L. \& P. C. Garnsworthy. 2002. Independent effects of dietary linoleic and linolenic fatty acids on the conjugated linoleic acid content of cows' milk. Anim. Sci. 74:163-176. https://doi.org/10.1017/S1357729800052334

Lordan, R., A. Tsoupras, B. Mitra, \& I. Zabetakis. 2018. Dairy fats and cardiovascular disease: Do we really need to be concerned? Foods. 7:29. https://doi.org/10.3390/ foods7030029

Mach, N., R. L. G. Zom, H. C. A. Widjaja, P. G. van Wikselaar, R. E. Weurding, R. M. A. Goselink, J. van Baal, M. A. Smits, \& A. M. van Vuuren. 2013. Dietary effects of linseed on fatty acid composition of milk and on liver, adipose and mammary gland metabolism of periparturient dairy cows. J. Anim. Physiol. Anim. Nutr. 97: 89-104. https://doi. org/10.1111/jpn.12042

Mahdavi, A., A. Mahdavi, B. Darabighane, A. Mead, \& M. R. F. Lee. 2019. Effects of soybean oil supplement to diets of lactating dairy cows, on productive performance, and milk fat acids profile: a meta-analysis. Ital. J. Anim. Sci. 18:809819. https://doi.org/10.1080/1828051X.2019.1585211

Martin, C., J. Rouel, J. P. Jouany, M. Doreau, \& Y. Chilliard. 2008. Methane output and diet digestibility in response to feeding dairy cows crude linseed, extruded linseed, or linseed oil. J. Anim. Sci. 86:2642-2650. https://doi.org/10.2527/ jas.2007-0774

McKain, N. K. J. Shingfield, \& R. J. Wallace. 2010. Metabolism of conjugated linoleic acids and 18:1 fatty acids by ruminal bacteria: products and mechanisms. Microbiol. 156:579e88. https://doi.org/10.1099/mic.0.036442-0 
Ménard, O., S. Ahmad, F. Rousseau, V. Briard-Bion, F. Gaucheron, \& C. Lopez. 2010. Buffalo vs. cow milk fat globules: Size distribution, zeta-potential, compositions in total fatty acids and in polar lipids from the milk fat globule membrane. Food Chem. 120:544-551. https://doi. org/10.1016/j.foodchem.2009.10.053

Selim, S. \& E. Hussein. 2020. Production performance, egg quality, blood biochemical constituents, egg yolk lipid profile and lipid peroxidation of laying hens fed sugar beet pulp. Food Chem. 310: 125864. https://doi.org/10.1016/j. foodchem.2019.125864

Shingfield, K. J., M. Bonnet, \& N. D. Scollan. 2013. Recent developments in altering the fatty acid composition of ruminant-derived foods. Animal. 7:132-162. https://doi. org/10.1017/S1751731112001681

Shingfield, K. J., S. Ahvenjärvi, V. Toivonen, A. Vanhatalo, P. Huhtanen, \& J. M. Griinari. 2008. Effect of incremental levels of sunflower-seed oil in the diet on ruminal lipid metabolism in lactating cows. Br. J. Nutr. 99:971-983. https://doi.org/10.1017/S0007114507853323

Simopoulos, A. P. 2016. An Increase in the omega-6/omega-3 fatty acid ratio increases the risk for obesity. Nutrients. 8:128. https://doi.org/10.3390/nu8030128

Sjaunja, L. O., L. Baevre, L. Junkkarinen, J. Pedersen, \& J. Setala. 1991. A Nordic proposal for an energy corrected milk (ECM) formula. Performance recording of animals. State of the art. EAAP Publ. 50:156-157.
Suksombat, W., L. P. Thanh, C. Meeprom, \& R. Mirattanaphrai. 2014. Effects of linseed oil or whole linseed supplementation on performance and milk fatty acid composition of lactating dairy cows. Asian Australas. J. Anim. Sci. 27:951959. https://doi.org/10.5713/ajas.2013.13665

Suksombat, W., L. P. Thanh, C. Meeprom, \& R. Mirattanaphrai. 2016. Effect of linseed oil supplementation on performance and milk fatty acid composition in dairy cows. Anim. Sci. J. 87:1545-1553. https://doi.org/10.1111/asj.12609

Tyrell, H. F. \& J. T. Reid. 1965. Prediction of the energy value of cows milk. J. Dairy Sci. 48:1215-1223. https://doi. org/10.3168/jds.S0022-0302(65)88430-2

Van Soest, P. J., J. B. Robertson, \& B. A. Lewis. 1991. Methods for dietary fiber, neutral detergent fiber, and nonstarch polysaccharides in relation to animal nutrition. J. Dairy Sci. 74:3583-3597. https://doi.org/10.3168/jds. S0022-0302(91)78551-2

Vargas, J. E., S. Andrés, L. López-Ferreras, T. J. Snelling, D. R. Yáñez-Ruíz, C. García-Estrada, \& S. López. 2020. Dietary supplemental plant oils reduce methanogenesis from anaerobic microbial fermentation in the rumen. Sci. Rep. 10:1613. https://doi.org/10.1038/s41598-020-58401-z

Ye, J. A., C. Wang, H. F. Wang, H. W. Ye, B. X. Wang, H. Y. Liu, Y. M. Wang, Z. Q. Yang, \& J. X. Liu. 2009. Milk production and fatty acid profile of dairy cows supplemented with flaxseed oil, soybean oil, or extruded soybeans. Acta Agric. Scand. A. Anim. Sci. 59:121-129. https://doi. org/10.1080/09064700903082252 